\title{
Plasma or serum from patients with systemic sclerosis alters behaviour of normal erythrocytes
}

\author{
I B KOVACS, M H A RUSTIN, R H MEYRICK THOMAS, C RIDLER, \\ S O SOWEMIMO-COKER, ${ }^{*}$ AND J D T KIRBY
}

From the Department of Dermatology and ${ }^{*}$ Department of Clinical Pharmacology, St Bartholomew's Hospital, West Smithfield, London EC1A 7BE

SUMMARY Incubation of washed normal erythrocytes with fresh or frozen plasma or serum from patients with systemic sclerosis (SS) significantly decreased the filterability of the cells, whereas the incubation of homologous normal serum or plasma with washed erythrocytes did not alter the filterability of these cells.

The endothelial cell adherence of normal erythrocytes was increased by $3 \cdot 5-$ and $2 \cdot 6$-fold $(\mathrm{p}<0.01)$ respectively when plasma or serum from patients with SS rather than that from normal controls was added to the incubation medium.

Further investigation and isolation of the reactive material(s) present in the serum and plasma of patients with SS, which affect the deformability and endothelial cell adherence of erythrocytes, may be helpful in understanding the pathogenesis of the disease.

Key words: erythrocyte deformability, erythrocyte filterability, erythrocyte-endothelial adherence.

The pathogenesis of SS is poorly understood. ${ }^{1}$ Investigation has focused mainly on three areas: connective tissue disturbances, immunological abnormalities, and microvasculature changes. There are reported abnormalities of the serum and plasma of patients with SS which include hypergammaglobulinaemia, ${ }^{2}$ hyperfibrinogenaemia, ${ }^{3}$ hyperviscosity, ${ }^{45}$ and altered fibrinolytic activity. ${ }^{3}$

Moreover, the serum has been reported to cause abnormalities in the behaviour of normal cells when these are incubated with the serum. These abnormalities include the increased growth of fibroblasts that have high levels of collagen synthesis, ${ }^{6}$ suppression of the mitogenic activity of lymphocytes, ${ }^{\text {and }}$ also cytotoxicity to cultured endothelial cells. ${ }^{89}$

In previous studies we found decreased filterability of SS erythrocytes ${ }^{10}$ and an increased adherence of these erythrocytes to cultured endothelium. ${ }^{11}$ In this study, by using a more sensitive technique, we show the influence of plasma and serum from patients with SS on the filterability of normal erythrocytes and show that the adherence of these normal erythrocytes to cultured endothelium is also

Accepted for publication 23 November 1984.

Correspondence to Dr I B Kovacs, Department of Dermatology, St Bartholomew's Hospital, West Smithfield, London EC1A 7BE. increased by the addition of plasma or serum from patients with SS to the incubation medium.

\section{Patients and methods}

\section{PATIENTS}

Twenty-six patients ( 22 female and four male) with SS diagnosed according to the American Rheumatism Association (ARA) criteria $^{12}$ with varying clinical manifestations and 26 age and sex matched controls were studied. The patients had a mean age of 49 years (range 21-67 years), and the average duration of the disease was 13.4 years.

\section{PLASMA, SERUM, AND ERYTHROCYTE SUSPENSION}

Fresh plasma samples were either used on the day of separation or were stored with the serum and deep frozen at $-20^{\circ} \mathrm{C}$ for later use. Aliquots of the frozen serum or plasma were thawed and filtered through $0.45 \mu \mathrm{m}$ pore size before use. Heat-treated serum was obtained by incubation at $60^{\circ} \mathrm{C}$ for 30 minutes. For each experiment fresh plasma, frozen plasma, and frozen serum from age and sex matched controls were used for comparison.

Erythrocytes were separated from heparinised blood $(15 \mathrm{U} / \mathrm{ml})$ by centrifugation $(800 \mathrm{~g}$ for $30 \mathrm{~min}$ at room temperature). The buffy coat was carefully 
removed and the cells were washed once in three times the volume of phosphate-buffered sodium

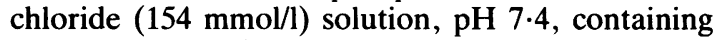
$0.25 \%$ human albumin (PBS). $1 \mathrm{ml}$ plasma or serum from a patient with SS or from a normal subject was incubated with $1 \mathrm{ml}$ packed cells at room temperature $\left(25^{\circ} \mathrm{C}\right)$ for 60 minutes. The cells were stirred every 10 minutes during the one-hour incubation then spun down at $400 \mathrm{~g}$ for 15 minutes, washed twice with 10 times the volume of PBS, and finally the packed cell volume was adjusted to $1 \%(\mathrm{v} / \mathrm{v})$ with PBS.

\section{FILTERABILITY MEASUREMENT}

Filtration of the erythrocyte suspension was measured by the apparatus shown in Fig. 1. In principle the cell suspension was filtered by gravity through a Nuclepore filter (13 mm diameter, $3 \mu \mathrm{m}$ pore size), and the filtrate was collected in a tube attached to a strain gauge. The output of the strain gauge was amplified to give $10 \mathrm{~cm}$ deflection per

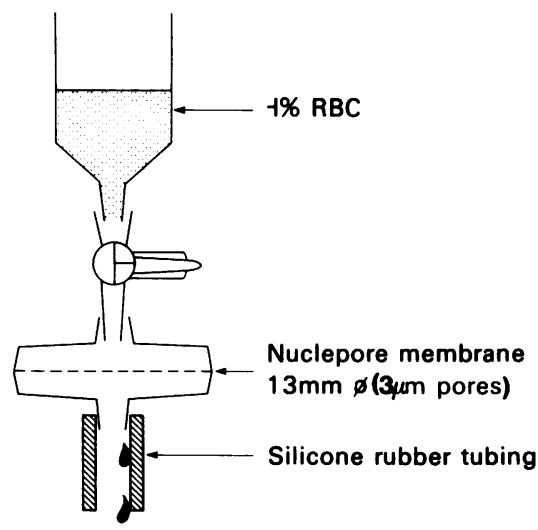

Drop catching filter $\rightarrow$ paper roll

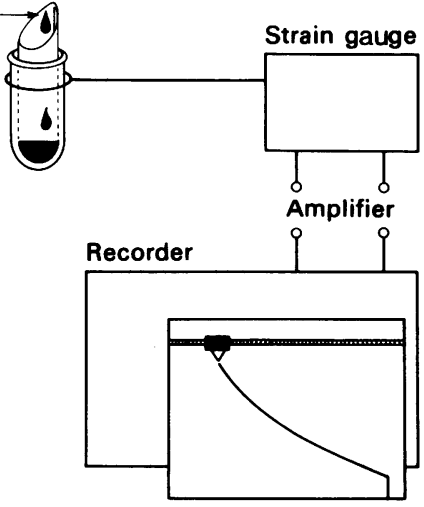

Fig. 1. Schematic diagram of the technique used for measuring erythrocyte filterability. millilitre of filtrate on a chart recorder $(5 \mathrm{~mm} / \mathrm{s})$. 음

With the three-way tap open the filter holder was filled up with PBS from below via the silicone $\stackrel{\vec{P}}{\stackrel{9}{9}}$ rubber outlet tube, ensuring that no air bubbles? were introduced. The tap was then closed and an empty $2 \mathrm{ml}$ syringe was inserted into the luer of the $\frac{\bar{\rho}}{\bar{\sigma}}$ filter holder, filled with $2 \mathrm{ml}$ PBS, and then尺 measurement was started by opening the three-way» tap. A steady tracing of the filtration over $10-$ seconds was obtained by allowing the drops to fall ${ }^{\circ}$ onto filter paper inserted into the collecting tube. $\vec{\omega}$ When the filtration of PBS was completed, the three-way tap was closed (the filter holder remained filled with PBS) and a new empty syringe wase inserted into the luer of the filter holder. After placing $2 \mathrm{ml} 1 \%$ erythrocyte suspension into the syringe the measurement was started again byo opening the three-way tap and simultaneously start-윽 ing the movement of paper of the chart recorder.The filtrate was first made up of the PBS remaining in the filter holder (which again allows the deter- $\bar{D}$ mination of the slope of the filtration rate of PBS). $\vec{\bullet}$ The appearance of the cells in the filtrate caused aog sharp deviation of the slope of the filtrate $v$ time curve and the filtration rate of cells was calculated from that point (see Fig. 2).

The technique described above virtually elimin ates the problem of clogging the pores of the filtero by leucocytes. Very few leucocytes $(<1 \%)$ and no platelet aggregates were seen clogging the pores of the filter (after 10 seconds of filtration) by scanning 3 electron microscopy or by fluorescence microscopy provided the platelets were made selectively fluores cent in the cell suspension. ${ }^{13}$

ENDOTHELIAL ADHERENCE OF ERYTHROCYTES Endothelial cells were obtained from human umbilical cord veins and grown confluently in $13 \mathrm{~mm}$ tissue culture wells. The adhesion of erythrocytes to cultured endothelium was measured as described? earlier in detail. ${ }^{11} 0.5 \mathrm{ml}$ of ${ }^{51} \mathrm{Cr}$-labelled erythro $\frac{D}{0}$ cytes $(50 \%, \mathrm{v} / \mathrm{v})$ and $0.5 \mathrm{ml}$ plasma or serum from? controls or SS patients were placed into each welfs and incubated in duplicate at $37^{\circ} \mathrm{C}$ for one hour. The non-adherent cells were decanted, the endothelium was washed six times, and the adherent erythrocytes ${ }^{\omega}$ lysed in $1 \%$ Triton $\mathrm{X}-100$. The radioactivity of the final lysate was measured. The adherence of erythrocytes incubated with $0.5 \mathrm{ml}$ PBS was also determined. From the specific activity of the erythrocyte suspension the radioactivity of the samples was expressed as the number of adhered䧇 cells.

$\left[{ }^{3} \mathrm{H}\right]$ Adenine uptake by cultured endothelium wa 
(a)

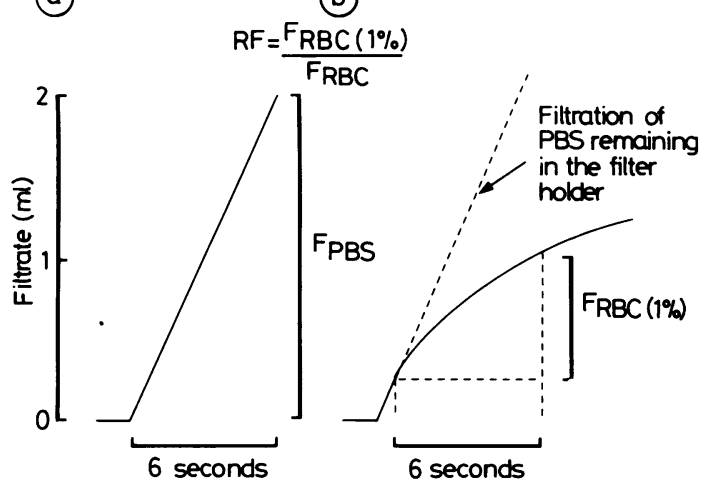

Fig. 2 Analysis of the filtration records. (a) Filtration rate of the suspending medium (PBS); (b) Filtration rate of the $1 \%$ cell suspension. For further explanation see 'Methods'. $R F=$ relative filterability. $R B C=$ red blood cells.

used as a sensitive assay to determine whether any endothelial damage was induced by the incubation with SS plasma. ${ }^{14}$ Endothelial cells were incubated with $0.5 \mathrm{ml}$ plasma in $13 \mathrm{~mm}$ diameter wells at $37^{\circ} \mathrm{C}$ for one hour, washed six times, and the cells solubilised in $0 \cdot 1 \mathrm{ml}$ formic acid. Radioactivity of the solubilised cells incubated with normal or SS plasma was measured and compared.

\section{Results}

The relative filterability $\times 10^{-3}$ (means \pm SEM) of washed erythrocytes from 10 normal subjects was $255 \pm 14$ and that did not statistically differ from the values obtained when the cells were incubated with homologous normal plasma or serum before the filterability measurement (Table 1 , see 'Controls'). Plasma or serum from patients with SS significantly decreased the filterability of normal erythrocytes

Table 1 Filterability of normal human erythrocytes after incubation with plasma or serum from normal controls and patients with systemic sclerosis (SS)

\begin{tabular}{|c|c|c|}
\hline \multirow[t]{2}{*}{ Specimen } & \multicolumn{2}{|c|}{ Relative filterability $\times 10^{-3}$ (means $\left.\pm S E M\right)$} \\
\hline & Controls & $S S$ \\
\hline Fresh plasma & $265 \pm 13(20)$ & $190 \pm 9^{*}(20)$ \\
\hline Frozen plasma & $284 \pm 22(10)$ & $216 \pm 12^{*}(10)$ \\
\hline Frozen serum & $269 \pm 18(10)$ & $174 \pm 14^{*}(10)$ \\
\hline
\end{tabular}

Duplicate measurement of each sample. Number of samples in brackets.

${ }^{*}$ Significance of difference from the controls $(p<0 \cdot 01)$.
(Table 1) and heat-treated sera $\left(60^{\circ} \mathrm{C}\right.$ for 30 minutes) had the same effect (data not shown).

The number of normal erythrocytes adhering to cultured endothelial cells was not influenced significantly by the presence of plasma or serum from normal subjects in the incubation medium. A 3.5and $2 \cdot 6$-fold increase in the number of adherent cells was observed when plasma or serum from patients with SS was present respectively during the incubation (Table 2). In a separate experiment the cytotoxicity of normal and SS plasma to cultured endothelial cells during the one hour incubation was tested by measuring the $\left[{ }^{3} \mathrm{H}\right]$ adenine uptake of the endothelium. No difference was found in the radioactivity of the cells incubated with normal and SS plasma, and the values did not differ from the uptake measured in the absence of plasma (Table 2).

Table 2 Effect of plasma and serum from controls and patients with systemic sclerosis (SS) on adhesion of

${ }^{51} \mathrm{Cr}$-labelled normal erythrocytes to cultured human endothelial cells

\begin{tabular}{lll}
\hline Specimen & \multicolumn{2}{l}{ Number of adhered cells $\times 10^{\circ}$ (means \pm SEM) } \\
\cline { 2 - 3 } & Normal & SS \\
\hline Plasma & $4 \cdot 18 \pm 0 \cdot 9(12)$ & $14 \cdot 27 \pm 1 \cdot 4^{*}(12)$ \\
Serum & $6 \cdot 17 \pm 1 \cdot 2(8)$ & $16 \cdot 06 \pm 2 \cdot 3 \quad(11)$ \\
\hline & $l^{3} H J$ Adenine uptake of endothelial cells $(\mathrm{cpm} /$ well) \\
\cline { 2 - 2 } Plasma & $852 \pm 39$ & $889 \pm 42$ \\
\hline
\end{tabular}

Number of samples in brackets.

Adhesion to plastic (without endothelial cells) was $8.7 \times 10^{5}$ and $0.6 \times 10^{5}$ cells in the experiments testing the plasma and serum respectively.

$\left[{ }^{3} \mathrm{H}\right]$ Adenine uptake of endothelial cells in plasma-free medium was $890 \pm 51 \mathrm{cpm}$.

${ }^{*}$ Significance of difference from the normal controls $(p<0 \cdot 01)$.

\section{Discussion}

Plasma proteins are known to influence the morphological and functional characteristics of erythrocytes. ${ }^{15} 16$ Earlier, when we measured decreased filterability of erythrocytes from patients with SS, washed cells were used for the measurement. ${ }^{10} 11$ It is known, however, that the surface coat of adsorbed plasma proteins cannot completely be removed even by repeated washings. Our present finding that the incubation of washed normal erythrocytes with SS plasma or serum decreased their filterability, measured by a new and sensitive technique, supports the previous suggestion that plasma factor(s) may account for the abnormal deformability of erythrocytes in SS. Fibri- 
nogen and cryoglobulins cannot be the reactive materials, as the sera, and filtrate of the deep frozen sera were equally as effective as fresh plasma. Also the plasma factor must be heat stable, as the activity of the plasma did not change after 30 minutes incubation at $60^{\circ} \mathrm{C}$.

The increased adhesion of washed erythrocytes to endothelial cells was reported earlier by us. ${ }^{11}$ In that study the addition of autologous plasma to the incubation medium in a few cases further increased the adherence of the cells. That preliminary finding is now confirmed, as the adherence of normal erythrocytes was consistently increased by the addition to the incubation medium of fresh plasma or stored and filtered serum from patients with SS but not that from normal subjects. SS plasma/serum could alter the behaviour of the membrane of erythrocytes or of the endothelial cells, or both. As we found no difference in the adenine uptake of the endothelial cells after a short incubation with either normal or SS sera, the possibility of endothelial cytotoxicity of SS sera (during such a short incubation) was excluded.

Most of the reported activities of SS plasma/serum lack specificity for the disease. Autologous plasmainduced increase in erythrocyte adherence to endothelial cells was also found in sickle cell disease ${ }^{17}$ sera from subjects with both inflammatory and neoplastic diseases suppressed the mitogenic activity of lymphocytes. ${ }^{7}$ Serum-mediated endothelial cytotoxicity has also occurred in other connective tissue disorders. ${ }^{18}$ Although the serum abnormalities are not unique to patients with SS, they may play an important part in the pathogenesis of the disease, and improvement after treatment of severe SS by plasma exchange might support this view. ${ }^{19}$ The characterisation of the reactive material(s) in the sera of patients with SS offers the possibility of uncovering abnormalities that may be key factors in the disease process.

The authors wish to thank Dr J D Pearson, Vascular Laboratory, MRC Clinical Research Centre, Northwick Park, London, for his kind donation of cultured endothelial cells, and the North-East Thames Regional Health Authority and the Knights Bachelor Foundation for supporting this study.

\section{References}

1 Rodnan G P. In McCarty D J, ed. Progressive systemic $\Rightarrow$ sclerosis, arthritis and allied conditions. 9th ed. Philadelphia: Lea and Febiger, 1979: 762-809.

2 Stava Z. Serum proteins in scleroderma. Dermatologica 1968 ; 11: $147-50$.

3 Kallenberg C G M, Vellenga E, Wouda A A, The T H. Platelet $\frac{\omega}{T}$ activation, fibrinolytic activity and circulating immune complexes in Raynaud's phenomenon. J Rheumatol 1982; 9: 878-84.

4 Blunt R J, George A J, Hurlow R A, Strachan C J L, Stuart J. \% Hyperviscosity and thrombotic changes in idiopathic and $\vec{\circ}$ secondary Raynaud's syndrome. Br J Haematol 1980; 45: 651-8.

5 McGrath M A, Peek R, Penny R. Blood hyperviscosity with $\vec{\omega}$ reduced skin blood flow in scleroderma. Ann Rheum Dis 1977; 36: $569-74$

6 Botstein G R, Sherer G K, LeRoy E C. Fibroblast secretion in scleroderma. An alternative model of fibrosis. Arthritis Rheum i 1982; 25: 189-95.

7 Horwitz D A, Garrett M A. Lymphocyte reactivity to mitogens in subjects with systemic lupus erythematosus, rheumatoide arthritis and scleroderma. Clin Exp Immunol 1977; 27: 92-9. ज

8 Kahaleh M B, LeRoy E C. Endothelial injury in scleroderma. $J$ 음 Exp Med 1979; 149: 1326-35.

9 Cohen S, Johnson A R, Hurd E. Cytotoxicity of sera from patients with scleroderma. Arthritis Rheum. 1983; 26: 170-8.

10 Dowd P M, Kovacs I B, Bland C J H, Kirby J D T. Effect of $\overparen{D}$ prostaglandins $\mathrm{E}$ and $\mathrm{I}$ on red cell deformability in patients with $\overrightarrow{\mathrm{O}}$ Raynaud's phenomenon and systemic sclerosis. Br Med J 1981; 283: 350.

11 Kovacs I B, Sowemino-Coker S O, Kirby J D T, Turner P. Altered behaviour of erythrocytes in scleroderma. Clin Sci 1983; 65: 515-9.

12 Subcommittee for Scleroderma Criteria of the American $\overline{\bar{O}}$ Rheumatism Association Diagnostic and Therapeutic Criteria Committee. Preliminary criteria for the classification of systemic $\mathbb{D}$ sclerosis. Arthritis Rheum 1980; 23: 581-90.

13 Tangelder G J, Slaaf D W, Reneman R S. Fluorescent labelling $\overline{\bar{O}}$ of blood platelets in vivo. Thromb Res. 1982; 28: 803-20.

14 DeBono D P, Macintyre D E, White D J G, Gordon J L. Endothelial adenine uptake as an assay for cell or complemento mediated cytotoxicity. Immunology 1977; 32: 221-7.

15 Koyama T, Kikuchi Y. Reduced red cell filterability due to red cell-plasma protein interactions. Biorheology 1982;19: 579-85. 응

16 Talstad I, Scheie P, Dalen H, Roli J. Influence of plasma proteins on erythrocyte morphology and sedimentation. Scand $J_{3}$ Haematol 1983; 31: 478-84.

17 Hebbel R P, Yamada O, Moldow C F, Jacob H S, White J G윽 Eaton I W, Abnormal adherence of sickle erythrocytes to cultured vascular endothelium. J Clin Invest 1980; 65: 154-60. 을

18 Shanahan W R, Korn J H. Cytotoxic activity of sera from $D$ scleroderma and other connective tissue diseases. Arthritis $\underline{O}$ Rheum 1982; 25: 1391-5.

19 O'Reilly M J G, Talpos G, Roberts V C, White J M, Cotton N L T . Controlled trial of plasma exchange in treatment of Raynaud's phenomenon. Br Med J, 1979; i: 1113-5. 